\title{
Developing English Supplementary Reading Cards (ESRCs) for Young Learners to Promote Free Voluntary Reading Program
}

\author{
Utari Praba Astuti \\ Pendidikan Bahasa Inggris-Universitas Negeri Malang \\ Jl. Semarang 5 Malang. Email: utari_pastuti@yahoo.com
}

\begin{abstract}
In English classes, young learners are mostly put into intensive reading sessions as the main menu where the focus of the session is on young learners' academic achievement. As a result, it is far from promoting reading English for pleasure. Like other skills in life, young learners learn to read by reading. The more they read, the better their reading competence will be. The better they read, the more enjoyable they find the reading activity. These paradigms function as the basis of providing young learners with various reading materials to read and enough time to spend for reading. This study aimed at developing English supplementary reading material to support young learners to enjoy some reading activities. The Research and Development (R \& D) procedure was employed to perform the whole process of the development and validation. With the reading material developed available, young learners are supposed to enjoy reading their own choice at their own pace as they are put into a free voluntary reading program. As a result, young learners have shifted their negative mindset about reading activity.
\end{abstract}

Key Words: english supplementary reading cards, free voluntary reading program

\begin{abstract}
Abstrak: Dalam kelas bahasa Inggris, sebagian besar pelajar pemula dimasukkan ke dalam sesi membaca intensif, dengan fokus pada prestasi akademiknya. Akibatnya, jauh dari tujuan untuk mengenalkan membaca bahasa Inggris yang menyenangkan. Seperti keterampilan hidup lainnya, pelajar pemula belajar membaca bacaaan. Semakin banyak yang mereka baca, akan semakin baik kompetensi membaca mereka. Semakin baik mereka membaca, lebih menyenangkan mereka melakukan aktivitas membaca. Paradigma ini berfungsi sebagai dasar untuk menyediakan pelajar pemula dengan berbagai bahan bacaan untuk dibaca dan menyediakan waktu yang cukup untuk membaca. Penelitian ini bertujuan untuk mengembangkan bahan bacaan tambahan berbahasa Inggris untuk mendukung pelajar pemula agar menikmati kegiatan membaca. Prosedur Penelitian dan Pengembangan (R \& D) dipakai untuk seluruh proses pengembangan dan validasi. Dengan tersedianya bahan bacaan yang telah dikembangkan, pelajar pemula seharusnya menikmati kegiatan membacanya dengan pilihan dan kemampuan mereka sendiri karena mereka dimasukkan ke dalam program membaca bebas secara sukarela. Akibatnya pola pikir negatif mereka tentang aktivitas membaca telah bergeser.
\end{abstract}

Kata kunci: kartu bacaan bahasa Inggris pelengkap, program membaca bebas dengan sukarela

As the first foreign language taught at school in Indonesia, English has been put into the curriculum starting from as early as the elementary school level until the senior high school. Based on the Decree $f$ the Minister of Education and Culture No. 060/U/1993 dated $25^{\text {th }}$ February 1993, English could be taught to students starting from the fourth grade of the elementary school as one of local content subjects. In line with the decree, introducing English to young learners promotes advantages. Johnson (2009) and Rachmajanti (2005) agree that the earlier a child learns a foreign language, the higher his/her proficiency in the target language. This is due to the length of time a child has in acquiring the language. He/she has a longer period of time to get an exposure of the target language. In her study, Rachmajanti (2005) concluded that the teaching of English in the elementary school level had some impacts on the students' Eng- 
lish achievement in the first grade of lower secondary school. Thus, the idea of introducing English to young learners at that school level can be viewed as an attempt to equip young learners with basic knowledge and sufficient exposure of English so that they are more prepared to encounter more complex knowledge of English presented in higher level of education.

However, following the current government's plan to reduce the number of subjects taught in elementary schools, the researcher perceives that the status of English at this educational level is under consideration. Regardless of the debate on that matter, the necessity to master English in this global era is pivotal for students' life quality in their future. Also, until now it is understood that English is the major medium of communication among nations, and so acquiring English through formal and/or informal educational institution is still relevant.

The above facts, the positive impact on higher education level and the importance of acquiring English starting in the elementary school, have become the basic reasons for elementary schools to introduce English to their students starting from the fourth grade and/or earlier. One of the schools is the Laboratory Primary School of State University of Malang which is a private and national standardized school (SSN) having 'International Class Program' (ICP). In the ICP, English has been introduced to students as early as the first grade. Beside Indonesian, English has been used as a language of instruction in the science, mathematics, and English classes. One of the teachers said that she used English (at about 40\%) and Indonesian (at about 60\%) in her science and mathematics presentations.

In general, compared to the process of acquiring a native language (L1), the process of acquiring a foreign language (L2) mostly happens more formally through academic contexts such as schools. According to Listia and Kamal (2007), teachers of EYL classes face problems dealing with many aspects such as the availability of syllabus, curriculum, sufficient materials, supporting facilities, and their own knowledge about the teaching of EYL. However, they find out that those English teachers definitely believe that young learners will have more self-confidence when they are equipped with sufficient English educational experience to face more sophisticated materials given in higher educational level. So, young learners who learn English at elementary school level will definitely acquire personal and academic benefits.
Another influential factor affecting young learners learning a language is their interest which is, according to Hidi and Renninger (2006), 'the outcome of an interaction between a person and a particular content'. Similarly, Ebbers (2011) quotes Hidi's (2006) definition of interest as 'a unique motivational variable, as well as a psychological state that occurs during interactions between persons and their objects of interest, and it is characterized by increased attention, concentration and behavior'. In the teaching of EYL, approaches used are supposed to facilitate students with fruitful chances so that students have sufficient room to optimize the presence of interest and construct knowledge on their own in developing their English language competence. In constructivism paradigm, it is believed that students are able individuals whose active involvement should be optimized based on their own capabilities, background knowledge, and learning styles. So, it is understood that, with the help of English teachers as the facilitators, young learners develop their interest in English; this increases the quality of their engagement and concentration in doing tasks given and/or self-initiative actions to reach their self-satisfying accomplishment and to build their positive attitude towards English.

Young learner's interest, according to Hidi (2001), can psychologically be categorized into two, individual and situational interest. Individual interest tends to develop gradually together with the development of knowledge and value, and is internalized at a longer period of time. In contrast, situational interest may or may not have a long-term effect on individuals' knowledge and value as it is mostly triggered by something in the immediate environment. Hidi and her colleagues (Hidi, 1990; Hidi and Anderson, 1992; Hidi and Berndorff, 1998; Hidi and Harackiewicz, 2000, in Hidi, 2006) encourage teachers to stimulate situational interest through interesting and inspiring academic activities, relevant content areas and/or topics to help students gain the utmost academic achievement. Besides, with the availability of teachers' support and encouragement, young learners' situational interest may become their individual interest. In EYL classes, young learners' situational interest in English should be supported through their educational experience in and/or outside their English classes.

It is undeniable that young learners need to develop their language skills, including reading skill, as it gives personal as well as educational benefits. This is a logical reason to have a reading text presented at the beginning of every unit of a textbook. As stated 
by Johnson (2009) their reading activities provide chances to understand their own world more vividly such as meaningful information, universalities of moral values, emotion, and relationships among human beings. However, it is believed that reading a written text to complete an assignment is very different from reading for pleasure; it shows a different point of view in comparing intensive and extensive reading program. According to Mesmer (2008), young learners will find different experience when they are given time to read for enjoyment. They take their own time for savoring the feelings, senses, perceptions, and/ or insights that the text offers. This may create an entertaining environment which stimulates a higher level of intrinsic motivation and engagement from students (Li and Seedhouse, 2010; Johnson, 2009). So, it is understood that students' reading enjoyment plays an important role on their reading motivation. Providing opportunity to have access to sufficient and varied reading materials, schools can encourage their students to become lifelong readers. When elementary schools adapt the idea showing the enjoyment in the extensive reading program in EYL classes, young learners will find invaluable benefits.

Free Voluntary Reading basically focuses on reading for pleasure (Krashen, 2004). Besides, it is a private as well as individual activity; it is also a reading activity that supports young learners to become engaged readers (Beare, 2011, Nishino, 2007). Stephen Krashen (1993), who firmly believes in the value of reading for pleasure, states "When children read for pleasure, when they get "hooked on books".' Brown (2008) adds that an extensive reading activity leads students to enjoy reading, which arouses reading interest as they focus on the overall meaning of the written texts. So, ideally to support the joy of reading activity, the language used in extensive reading materials is not far beyond young learners' language competence. Scott and Nagy (2004) and Nation (1997) state that young learners should understand $90 \%-95 \%$ of word meanings in a text to be able to understand the overall ideas shared by the text.

It is natural to assume that young learners will be frustrated immediately after reading the first paragraph if they find so many words that they do not understand. According to Mesmer (2008), word difficulty is one of the first surface features that affect readability. Besides, the complexity of sentences used should be considered based on the students' language development so as to avoid so much misunderstanding.
Having informal discussions with several EYL teachers from different public elementary schools at the beginning of 2010, the researcher found out that the teachers believed that reading skill could be developed only by practicing reading; some of them related it to the slogan 'learning by doing'. That's why they always started the English class with a reading activity, the intensive reading activity. When asked about the extensive reading activity, not everybody had a clear idea about the activity. They just could not imagine the situation when their students join such an activity; moreover, the prerequisite of having sufficient number of reading materials provided for the students is considered as a big challenge.

Generally speaking, it is more reasonable to work with those teachers who have some experience in providing time and reading materials for the extensive reading program at school. In the preliminary study, the researcher decided to ask English teachers from the Laboratory Primary School of State University of Malang to work together during the study. They said that some years ago the teachers had the experience to handle a free voluntary reading activity once in a week for one semester with Indonesian reading materials provided for the students.

This study is aimed at supporting the development of young learners' reading interest in English as a concern of empowering young learners' capability and providing influential support to cultivate their interest. The fact showing that young learners nowadays can read but they do not read becomes the basic concern relating to young learners' reading interest.

Having decided to work with teachers at the Laboratory Primary School of State University of Malang, the researcher looks for more information about the students' needs from the headmaster, English teachers, and the librarian. In general, the students' English competence is good as they have sufficient English classes starting from their first grade.

Based on the importance of reading interest, it was decided to provide English supplementary reading material to support the development of students' reading interest through free voluntary reading program. With accessible English reading material available around them, young learners would be connected with language inputs which are of great influence to strengthen the development of their interest and positive attitude toward English. In his study, Doiron (2003) agrees that creating a conducive environment concerning students' reading competence provides a great opportunity for students to become successful 
readers in the target language. The availability of sufficient interesting reading material is an important facility which may help arouse reading interest as interest may serve to jumpstart the struggling readers (Hidi and Renninger, 2006; Ebbers, 2011) and strengthen students' belief of the importance of reading habits (Krashen, 2004). So, when students are interested in a reading activity, they will enjoy it. Also, they will not easily leave the enjoyment for the sake of other activities. This is the position where the students have acquired reading habits which is considered as a powerful and useful activity all along their life.

\section{METHOD}

As the objective is to develop reading material, the Research and Development procedure was employed. Inspired was models proposed by some experts, the researcher carried out the study based on the model proposed by Dick and Carey (1990) consisting of 10 components put into three broader phases, i.e pre-production, production, validation, and finalization phase, which are done sequentially.

Based on the real condition of the potential users, the objective (s) was set to keep the following steps on the right track. As decided, the students and the teachers of the Laboratory Primary School of State University of Malang were asked to work together during the study. It was identified that students' competence in English was good enough as English has been given from the first grade. There were two attainment levels that the students should achieve, the national standard and the Cambridge standard as the school was supervised by the Cambridge curriculum. English functions as a subject as well as a means of communication inside and outside the class. The fact showing that students were not interested in reading activity, and not everybody liked English became fundamental concern of this study. So, the objective is to assist young learners to read English reading material developed; by reading the material young learners were supposed to improve their interest in reading and build positive attitude in reading activity and learning English in general.

Based on the real condition of the potential users, the initial form of English reading material was proposed and reviewed by English teachers and some students to get some inputs on the forms, text types, vocabulary, and sentence patterns used.
The process of writing and adapting texts was started based on different sources such as school context, personal experiences, public places, television shows, children's storybooks, Internet, Encarta Kids, and Wildlife File. The sources were selected based on the contexts, topics, and complexity of contents which should be related to young learners' world.

There are five sets of English reading material developed, MY FAMILY set, AROUND THE SCHOOL set, FABLE set which are in the form of narrative texts, SIMPLE SCIENCE set is expository, POEM set consists of poems with different contexts and messages to share. MY FAMILY, AROUND THE SCHOOL, and POEM set were written by the researcher; the other sets were adapted from different sources.

The two native speakers were asked to evaluate the product focusing on the language use so as to put the texts on the acceptable English. After that, providing illustrations/pictures on each card was done by two illustrators. They were always reminded to focus on the most important part and/or topic of the text. When the product had been printed, EYL expert and printed -work expert evaluated the product. The results of the evaluation were used to revise the reading material.

When the ESRCs had been revised, TRY-OUT 1 was done with 12 students; they were supposed to come and read whenever they had time. It was really on the students' willingness to do the activity. Using an effort rubric, the students were observed. The quality of their engagement in the TSR was evaluated based on the behavioral characteristics proposed by McClure (2008). The discussions going on during the TSR were also recorded, and used to enrich the previous data collected. While the students were joining the try-out, the English teachers evaluated the product and observe the free voluntary reading program, 'Take, Sit, and Read' (TSR).

The product was revised based on the inputs given by the teachers and the students, as well as the researcher's field notes done during the try-out. The revision focused on the improvement of the product as well as the program where the product was used.

TRY-OUT 2 was done with the whole class of the other parallel class. This time the students were put in the free voluntary reading program as a classical program. The procedure and objective of the free 
voluntary reading program, the 'Take, Sit, and Read', were explained before the program started. The students' activities during the program were recorded based on their journals, follow-up tasks, discussions with the researcher and their peers. The researcher's field notes enriched the data collected throughout the reading program. The quality of the students' engagement during the program was evaluated by using the same rubrics. The data on their reactions were put into different codes, i.e. interest, reading activity, follow-up actions, and reflections. Besides, the revisions were done based on the results of the try-out 2.

Data analysis focused on the quality of the product and the acceptability of the product. The quality of the product covered the physical appearance, size of the cards, durability of the cards, number of cards, types of text, topics and contents. The acceptability of the product was indicated by the quality of young learners' performance, engagement, and reflection during the TRY-OUT sessions.

After TRY-OUT 2, it was noted that the ESRCs were physically interesting as they were able to attract young learners' attention. This can be identified as a basic quality of reading materials for reading for enjoyment. Besides, the topics in the ESRCs were suitable for young learners as they were able to learn lessons and state their reflections. The Indonesian contexts were used in the 'MY FAMILY', 'AROUND THE SCHOOL', and the poem set. The language used was at young learners' linguistic competence as they were able to understand texts in the ESRCs.

\section{FINDINGS \& DISCUSSION}

\section{The Results of the Development}

The product developed in this study is provided for young learners who need supplementary English reading material to arouse and maintain their reading interest. The ESRCs are intended to support the reading activity done outside the English class and to utilize the reading for pleasure program. As stated previously, the idea to provide time for young learners to read in free voluntary reading activity not only stimulates their reading interest but also promotes their cognitive as well as linguistic development.

On each card, there is one complete story, description/explanation or a poem. The length of each non-poem text is $325-425$ words as what is recommended by the English teachers because it is the 'boundary' of their students' concentration level. The stories are written in the present or past tenses, and there are a lot of direct conversations quoted within each text.

The poems are written in free-style forms with or without repetitions and/or rhyming words. The length of the poems is varied from $6-15$ lines. For example:

$$
\begin{gathered}
\text { C o mf ort } \\
\text { I'm warm!' the Sun said } \\
\text { I'm cold!' the Rain said } \\
\text { II make people healt hy.' the Sun said } \\
\text { II make people happy.' the Rain said } \\
\text { I'm cool,' the Breezy Wind said, } \\
\text { 'and I can make people sleepy.' }
\end{gathered}
$$

In this example, the poem shows how nature affects people's life. This is in fact very important as without the help from the nature people will not live comfortably. As a reflection, people should not do any harm to the nature. So, the follow-up activities lead the students to think about the above fact. For example, the students should complete the following sentence 'If there is no wind during the hot day,...

To introduce the sets of the ESRCs, the researcher provides an introductory card to tell young learners that the two sets of the whole sets, 'My Family' and 'Around My School', are written in the first person. The stories happen around the main character, Ado. For example, the story entitled 'My younger sister is here now with us' tells about Ado's unforgettable experience when he found out that his mother gave him a cute baby sister in that very early morning. He experienced various feelings all along that morning, worried, questioning, anxiety, surprised, and happy.

It was very early in the morning. I came
out of my room because I heard my dad
and my mom were busy. "I'll take your mom
to the hospital now. Today, prepare every-
thing by yourself before going to school.
Don't forget your breakfast. Bu As will help
you and Anto." My dad said. What I saw
there was very scary. I didn't know what
happened to my mom. It really hurt her. She
was struggling hard. She couldn't say any
word to me.

Putting the stories in the first person is purposefully done to encourage young learners as the intended readers to understand the idea of the stories, and they are able to relate what they can grasp from the stories they read with their own experience in life. 
Also, it shows that young learners act as the ones who the main character talks to. The idea suggests putting the stories close to the readers as if the readers could be involved in the stories.

There are five sets of the ESRCs each of which consists of different number of cards. The first set, My Family, consists of 15 different stories which are put into several topics such as sharing, appreciating, comforting each other, being proud, and being cooperative. The second set, Around my school, consists of 24 cards including the ideas of being good and/or not good students, helping each other, comforting each other, learning new things from others, showing empathy, and holding self-awareness. The poem set consists of 28 cards which provide messages showing the relationship between parents and children, children and their friends, children and nature, children and their environment, children and their belonging, children and their future imaginations, as well as children and their own feelings.

The fable set consists of 13 cards of stories which show that in this world there is the bad side and the good side, the wise and the tricky or wicked behaviors, as well as the strong and the weak characters. These ideas are put into stories with different main characters, such as a cat, a scorpion, a frog, a monkey, an elephant, swans, a lion, a crocodile, and a bear. To make it more natural, the characters are put into their real habitats such as a snowy area for the bear, a river for the crocodile, frog, and swans, and a forest for the lion and elephant. For example:

So, the frog agreed to take the scorpion across the river. He swam over the bank and stopped near the mud to pick up the scorpion. The scorpion then crawled onto the frog's back, and the frog slid into the river. The frog stayed near the surface so the scorpion would not drown. ('The Scorpion and the Frog')

Besides, in the process of adapting the fables, there are some steps to consider the texts. First, make the text shorter to meet the initial agreement on the number of words. Second, simplify the sentences to let the students enjoy the flow of the story. Third, minimize the use of 'unfamiliar' words to avoid putting students questioning about many unfamiliar words. Fourth, lessen 'dramatic' actions like hitting, killing, and eating others which may hurt students' feeling. For example:

The grasshopper didn't feel like singing any more. He was cold and hungry. He had nowhere to shelter from the snow, and nothing to eat. The meadow and the farmer's field were covered in snow, and there was no food to be had. 'Oh what shall I do? Where shall I go?' wailed the grasshopper. Suddenly he remembered the ant. 'Ah - I shall go to the ant and ask her for food and shelter!' declared the grasshopper, perking up. So off he went to the ant's house and knocked at her door. 'Hello ant!' he cried cheerfully. 'Here I am, to sing for you, as I warm myself by your fire, while you get me some food from that larder of yours!' (Original text of 'The ant and the grasshopper').

The grasshopper was cold and hungry. He had nowhere to shelter from the snow, and nothing to eat. Everything was covered in snow. There was no food to eat. 'Oh, what should I do? He thought. Suddenly, he remembered the ant. So he went to the ant's house. 'Hello ant!' he said cheerfully. 'Here I am to sing for you in your warm house. You just give me a little food for that.' (An adapted text of 'The ant and the grasshopper').

Comparing the two texts above, it is shown that the adapted text is shorter, simpler, and easier to understand. One of the native speakers said that it is more straightforward. However, the main series of action is still there to enjoy.

The simple science set consists of 12 cards of simple explanation and description about flora and fauna. There is some information about tomato, photosynthesis, ecosystem, and plants. Besides, the information about turtles, birds, tigers, giraffe, giant panda, chicken, and chimpanzee is provided to add young learners' knowledge of those animals about which the students possibly have already known.

It takes about 21 days, or three weeks, for a hen's egg to hatch. For this to happen, everything must be right for the egg. The egg needs shelter and the right climate. The egg needs to breath. The egg needs food. When the time comes, it also needs something sharp to crack the shell open. ('Chicken Egg').

Every young learner has a clear idea about what a hen's egg is. Most children like fried and/or boiled eggs. Even it can be said that it is their favorite dish. 
However, not very many children know an egg needs certain condition to become a baby chick.

The follow-up activities attached to those cards are varied as it involves their general knowledge, personal experience, critical thinking as well as kinesthetic. The questions can be about fact finding, inference or synthesizing. For example: (1) Mention some mountains in Indonesia that you remember. ('It's beautiful'/Around my school), (2) What is interesting and useful homework that you have ever had? ('Homework'/poem), (3) If you're asked to give her a name, what would you give her? ('It's crowded now'/My Family), (4) Color the following picture. ('Surprise'/poem), (5) Draw your own house, and color it. ('My House'/poem)

Besides, the students are asked to state their opinion about the stories and/or poems that they have already read. (1) Which character that you like? Why?, (2) Which character that you don't like? Why?, (3) What have you learned from the poem(s)?, (4) What you like/don't like about the story?, (5) What is your opinion about Ado's mother? ('It's raining hard'/My family).

They are also asked to give different titles to some stories and/or poems, and to make some stories end differently. As suggested, these follow-up activities are not the focus of the 'TSR' program. However, they are there to give more color to enrich the students' experience and provide different ways on how to deal with reading material.

The illustrations given to each card should be based on the principle that they sharpen the perception of children, stimulate their imagination and increase their sense of observation. They should also give precise description to avoid ambiguity (Segun, 1988). For example, Ado's expression of his anxiety is shown by the picture when he shouted at his brother ('My younger brother did not understand me'). So, all the illustrations are supposed to help children grasp the overall meanings of the reading material they read. Moreover, it is meant to attract children's attention, too.

The typographical features of the written texts including font, font size, space, layout, and paper sizes are supposed to add some positive points to the physical appearance of each card. The font used in this product is Kristen ITC or Arial as it shows clear character of each letter, and it provides some artistic feature to support relax and non-serious mode. The font size is flexible depending on the length of the text so as to put the whole text on one card.

\section{The Evaluations of the ESRCs}

The evaluation process of the ESRCs was done by different experts, i.e. two native speakers, a printed-work expert, an EYL expert, two English teachers. In between the processes, the revisions were done accordingly based on the inputs from the experts. Besides, the ESRCs were also validated through two try-out sessions; the ESRCs were used in the real context of school with the students of the fifth grade of the Laboratory Primary School of State University of Malang.

The inputs from the native speakers were responded and evaluated to perform the revisions accordingly. First, the grammatical points such as tenses, prepositions, articles, and adverbs of frequency were revised based on the inputs given. By doing so, the researcher had found some more revisions on basically the same matters by herself. Second, it was suggested having more and/or adding 'problems' to resolve in some stories. At least there were two stories which had been given some problems to resolve, i.e. in the 'We have a new friend'; it was told that the new friend, wanted to see a train which he had never seen before. But there was no train passing by the city they lived, so they had to go to a nearby city to see it. Another story entitled 'A Wonderful Holiday' had been provided with one 'problem' which involved all characters to solve; they were looking for Ado's brother around the house when they realized that he was not around with them.

Third, the importance of glossary to help students understand the stories, poems, and description more easily was accepted. So, it is provided in the introduction booklet. Fourth, another important thing to add was the exclamation expressions as without them the effect was not very powerful. It is hoped that young learners will find them as a tool to drive their involvement emotionally. Fifth, although the experts did not want to look over the content, they still gave some comments on how to make the stories go smoothly. So, some revisions had been done based on their inputs such as adding some ideas about what the students in the story have learned from the doctor they are talking to ("Visiting the Local Health Center), enriching the story by showing more important roles of the school janitor ('Pak Samad, how are you today?').

After the illustrators did their job on providing acceptable illustration on each card, they consulted the researcher and the printed-work expert to ask for their comments and inputs. The researcher evalu- 
ated the illustration based on her idea of each text and perspective on the importance of the illustration including effectiveness and attractiveness, while the expert evaluated the work based on the artistic features of the illustrations, physical appearance of the cards, and 'comfort' shared by every individual card.

The expert agreed that the pictures provided in each card of 'My Family' and 'Around my School' set should show the most 'important' moment of all. As the researcher writes the two sets, she gives inputs together with the expert. For example, in 'It is crowded now' young learners can see what a baby can do during late at night as there is a picture of a mother holding a crying baby at a late night shown by the clock on the wall.

The expert and the researcher agreed that it is easier to describe an action than an emotion and/or mood. The picture of a teacher who is teaching is easily described ('What does a teacher try to do to his/her students?'). However, the illustrator should think carefully how to describe a teacher who is happy with her students' work ('Let's keep ourselves clean'), and a cheerful teacher whom the students really love ('She is a cheerful teacher'). Those are done and evaluated carefully to provide meaningful, effective, and interesting illustrations.

In the poem set, not all of the pictures used to decorate as well as to help students to grasp the message within each poem are acceptable. There are some corrections on the following poems. (1) 'Picnic' (there should be no bread in the basket), (2) 'A Rainy Day' (the rain should be shown through the window), (3) 'What will be... will be' (the wading bird should be in the river), (4) 'A Surprise' (there should be raining effect shown), (5) 'If I were...' (The professions should only include those mentioned in the poem), (6) 'Pinky Roses' (the girl should look happy), (7) 'Tongue' (the tongue should be described nicely, but not 'dramatically').

Artistically, a title can be put at the top or at the bottom of the card. So, there are three poems having the title at the bottom, i.e. 'Tongue', 'My House', and 'Newspaper'.

The expert has no correction on the fable set, and he thinks that the illustrations on those cards are sufficient, and they function perfectly. They help young learners to 'see' what a witch looks like, how the swans bring the turtle to a beautiful lake, or how the ant brings grain by grain of wheat on his back. $\mathrm{He}$ also has the same opinion about the simple science cards. Young learners can see how turtles confuse floating plastic garbage with jellyfish, and how the mother hen sits over the eggs to keep the eggs at the right temperature. So, the illustrations have functioned appropriately in helping young learners understand each text.

In general, the EYL expert thinks that the ESRCs share positive and constructive exposures to elicit different even better perspective of how to behave appropriately, nicely, and friendly so as to promote good living to young learners. Besides, the ESRCs are considered as 'unique' reading material because of its physical appearance and content. The reading cards for young learners are rarely found, and topics covered in this product are about 'simple' things which are usually not intentionally and seriously considered as influential pieces of events, such as the first day of school experienced by young learners, how young learners see adults' world, how young learners realize that they are not alone in this marvellous world, and how young learners realize that their parents are very proud of them.

Using an evaluation form, the expert evaluated the ESRCs card by card focusing on the characteristics of an acceptable reading material for reading for pleasure activities.

From the Table 1, it is shown that the expert strongly agrees with all the aspects of the evaluation. Although she accepts that the length of most texts are appropriate, she states there are some texts which are considered too long, i.e. 'It's a great story', 'My first day of school', 'What does a teacher do when school holiday comes?', 'The Monkey and the Crocodile', and 'The Secret Life of Birds'. The revision is done by reducing several sentences which may or may not affect the flow of the stories. It is done under more important consideration, i.e. to meet the readability level of the product.

The types of text provided are varied enough to give the students sufficient exposure on different text types. In fact, she supports the idea of providing various texts to enrich students' experience in facing real world of literature. This also may arouse students' interest to different topics. She thinks that the product covers sufficient and suitable topics which are close to young learners' world. According to her, it is easier to grasp the ideas when the texts are put in young learners' point of view. As a result, they will be more motivated as they find reading materials meaningful.

As shown in the Table 1, the expert agrees that vocabulary and sentence structures used in most texts are at students' level of language competence. In other words, they can understand most texts 
Tabel 1. The Results of Validation from EYL Expert (Non-Poem)

\begin{tabular}{clll}
\hline No & \multicolumn{1}{c}{ Evaluation Aspect } & \multicolumn{2}{c}{ Results } \\
\hline $\mathbf{1}$ & The length of text & 3.90 & SA \\
$\mathbf{2}$ & Type of text available & 3.98 & SA \\
$\mathbf{3}$ & Topic discussed & 3.97 & SA \\
$\mathbf{4}$ & Level of difficulty of vocabulary used & 3.80 & SA \\
$\mathbf{5}$ & Level of difficulty of sentence structure & 3.90 & SA \\
$\mathbf{6}$ & Readability of text & 3.80 & SA \\
$\mathbf{7}$ & Suitability of pictures provided & 3.94 & SA \\
$\mathbf{8}$ & Appropriateness of colors (background and & 3.98 & SA \\
& pictures) & 3.90 & SA \\
$\mathbf{9}$ & Lay-out & 4.00 & SA \\
$\mathbf{1 0}$ & Paper size & 4.00 & SA \\
\hline $\mathbf{1 1}$ & Font and font size & &
\end{tabular}

without bothered by unfamiliar words and sentence patterns. The use of unfamiliar words and longer complex sentences cannot be avoided; however, it should be minimized. This also supports the readability of text which helps young learners to understand and to relate the content and message with their own previous knowledge and experience.

In the last five aspects evaluated, the expert definitely agrees with all cards, and gives no significant inputs. She states that it is easy and clear to catch word by word written in each text as the letters are in black written on bright-colored background. Also, the illustrations are not too much, and function appropriately. Moreover, she mentions that the pictures are original. This is important as to avoid breaking the rules of copyright.

For the follow-up activities, she proposes to add some more activities such as predicting what happens to the fox ('The Lion and Bad Breath'), stating opinion about being a good teacher ('She is a cheerful teacher') or having a fried egg as their breakfast ('Chicken Eggs'). Besides, she suggests that instructions for the follow-up activities be made clearer so that young learners understand what is actually asked and/or what they have to do/perform.

The poems are evaluated using a form with several different aspects to focus on. However, there are some similarities aspects such as the relationship between the content and the pictures, colors of background and pictures, lay-out, paper size, and font and font size (Table 2).

The poems evaluated are, according to the expert, about 'examples' of how people should live at this beautiful world. It is good and effective if students can really understand the poem they read. They are able to identify the message, and then they can make some reflection on their own experience and/or situation where they are involved. So, to identify how far students can learn a lesson from a poem they read, the researcher provides follow-up activities covering the ideas above, such as (1) What is the poem about?, (2) Do you like the poem? Why?, (3) What can you learn from the poem?, (4) When did you start riding a bicycle? ('Wow'), (5) What activities do you usually do together with your daddy? ('The Conversation').

The expert states that she does not mind with the length of the poems as long as they have 'elaborated' what they are intended to explore. Comparing the longest ('Good or not Good') and the shortest ('Comfort') poems, she states that both poems have the same sort of message to grasp, i.e. how to appreciate. The first focus on how to appreciate others' opinion, and the latter is about how to appreciate the nature. She thinks that the length of the poems is reasonably accepted.

There are sufficient sentence patterns repeated within one poem. She approves this is important to give young learners enough room to internalize different sentence patterns they have or have not learned. Moreover, the use of some 'unfamiliar' words is reasonably accepted so as to enlarge young learners' vocabulary repertoire.

Similar to the non-poem texts, for the poem set she also definitely agrees with the last five aspects evaluated, i.e. pictures (illustration), color of background, lay-out, paper size, and font as well as font size. The proportion of the illustration and text is good; it shows that they support one another. The illustration will be nothing without the text, and it happens on the other way around.

Based on the inputs given by the EYL expert, the revisions have been performed immediately, 1) to shorten five texts considered too long by reducing 
Tabel 2. The Results of Validation from EYL Expert (poem)

\begin{tabular}{clll}
\hline No & \multicolumn{1}{c}{ Evaluation Aspect } & \multicolumn{2}{c}{ Results } \\
\hline $\mathbf{1}$ & Content of poem & 3.80 & SA \\
$\mathbf{2}$ & Message embedded & 3.90 & SA \\
$\mathbf{3}$ & Length of poem & 3.82 & SA \\
$\mathbf{4}$ & Vocabulary used & 3.80 & SA \\
$\mathbf{5}$ & Level of difficulty of phrase/sentence & 3.94 & SA \\
& structure & & \\
$\mathbf{6}$ & Suitability of pictures provided & 3.90 & SA \\
$\mathbf{7}$ & Appropriateness of colors (background and & 3.90 & SA \\
& pictures) & 3.98 & SA \\
$\mathbf{8}$ & Lay-out & 4.00 & SA \\
$\mathbf{9}$ & Paper size & 4.00 & SA \\
$\mathbf{1 0}$ & Font and font size & &
\end{tabular}

sentences, paraphrasing some long sentences, and/ or cutting off some pieces of events; 2) to make corrections on vocabulary and grammar; 3 ) to restate the instruction in the follow-up activity booklets; 4 ) to add some more activities such as predicting what happens to the main character, stating opinion of being in the main character's position, or proposing a solution for the main character's problem.

Although it is not very easy to shorten or simplify a text, the researcher thinks that to keep the main points of the story and the flow of the plot should be prioritized. It is a good idea to add some more activities proposed as those activities help the researcher to understand whether the students understand the texts, and whether they have explored their ability to think critically while reading. Besides, the students have a room to relate the ideas in the texts with their own experience.

The English teachers basically agree that the reading material is suitable for young learners. It has a lot of moral values which function as a reflection to broaden young learners' horizon and/or perspectives. Besides, it gives various inspirations that may affect young learners' behavior, effort, and/or idea in facing and handling challenges and problems in their daily life.

The evaluation forms provided for the teachers have the same aspects as those for the EYL expert. However, there are some additional aspects on the possible implementation of using the product, i.e. the product used in voluntary reading activities, the product used as additional recourses for class activities, and the product inspires teachers for their class activities (Table 3).

When asked about the idea to provide glossary, they then support the idea and propose to have the translations of the words. Besides, they believe that the sentence patterns and length of sentences used are reasonable enough for young learners. So, the texts' readability is accepted as at young learners' level of their English competence.

Tabel 3. The Results of Validation from English Teachers (non-poem)

\begin{tabular}{clll}
\hline No & \multicolumn{1}{c}{ Evaluation Aspect } & Results \\
\hline $\mathbf{1}$ & The length of text & 3.48 & A \\
$\mathbf{2}$ & Type of text available & 3.65 & SA \\
$\mathbf{3}$ & Topic discussed & 3.65 & SA \\
$\mathbf{4}$ & Level of difficulty of vocabulary used & 3.50 & SA \\
$\mathbf{5}$ & Level of difficulty of sentence structure & 3.55 & SA \\
$\mathbf{6}$ & Readability of text & 3.55 & SA \\
$\mathbf{7}$ & Suitability of pictures provided & 3.70 & SA \\
$\mathbf{8}$ & Appropriateness of colors (background and & & \\
& pictures) & 3.97 & SA \\
$\mathbf{9}$ & Lay-out & 3.97 & SA \\
$\mathbf{1 0}$ & Paper size & 4.00 & SA \\
$\mathbf{1 1}$ & Font and font size & 4.00 & SA \\
$\mathbf{1 2}$ & Used as material for voluntary reading & 3.95 & SA \\
& activities & & \\
$\mathbf{1 3}$ & Used as instructional resources/media & 4.00 & SA \\
$\mathbf{1 4}$ & Used as inspiring materials for teachers & 3.95 & SA \\
\hline Strongly Agree (SA) = 4; Agree (A) = 3; Tend to Disagree (TD) $=2 ;$ Strongly Disagree (SD) = 1
\end{tabular}


For the next five aspects, both of them agree that those aspects are perfectly done as the results show that the cards are interesting, attractive, meaningful, and acceptable. The physical appearance of each card is interesting, and it can attract young learners' attention. Besides, all aspects available in each card have meanings. The pictures and/or illustrations mingle with the texts to help each other to clarify ideas and entertain young learners as the readers. The size of the cards is at 'usual' size of instructional material provided for class materials. They do not have any specific comments about the font and font size. In other words, they definitely agree with the font and font size used in each card.

The teachers also evaluate the poems cards by using a similar form used by the EYL expert. However, there are some differences in the importance and the usefulness of the product developed (Table 4).

According to the teachers, the content of the poems are sufficiently varied. For example, there are poems about the relationship between children and their belongings such as books, toys, house, and pets. It shows a 'beautiful' mutual understanding between children and their belongings. A house may protect them from the sun and the rain; that's why it deserves something amusing like being painted in a new color.

The poems may share explicit and implicit messages. The teachers agree that the messages of all poems are about positive and constructive moral values. Young learners can learn lessons from the poems by understanding the explicit meanings as well as thinking critically about the implicit messages. So, there is no good reason to prevent young learners from reading and enjoying the poems.

The length of the poems is varied; however, it does not mean that the shorter the poem, the more explicit the meaning. For example, 'Comfort' is the shortest poems consisting 6 short sentences. The teachers say that the explicit meaning of the poem is very simple as the nature in this case the sun, the rain, and the wind performs their individual duty to give people comfort. In addition, young learners may be encouraged to learn more lessons such as how to appreciate what nature has given to people, and how to express deep gratitude to God as the creator of the nature. This is actually the very end of the aim shared by the poem.

There is no significant comment from the teachers about the length of sentences used in the poems. They just state that they like rhyming poems. The repeated sentence patterns are such a good idea to give young learners a room to internalize the patterns. Also, they definitely agree with what are provided on each card including the pictures, background, layout, font, and font size.

The poems may function as instructional resources, instructional media, and a supplementary reading material to enrich the English atmosphere around the class and the school. Besides, one of the teachers, states that the poems are good models for young learners to write their own poems.

The various follow-up activities are also important, as the teachers agree that they are important to help young learners understand the messages shared by each poem. According to the teachers, their students are used to having a set of exercises or tasks

Tabel 4. The Results of Validation from English Teachers (poems)

\begin{tabular}{|c|c|c|c|}
\hline \multirow{2}{*}{\begin{tabular}{c|c} 
No \\
1
\end{tabular}} & \multirow{2}{*}{$\begin{array}{r}\text { Evaluation Aspect } \\
\text { Content of poem }\end{array}$} & \multicolumn{2}{|c|}{ Results } \\
\hline & & 3.48 & $\mathrm{~A}$ \\
\hline 2 & Message embedded & 3.50 & SA \\
\hline 3 & Length of poem & 3.50 & SA \\
\hline 4 & Vocabulary used & 3.48 & A \\
\hline 5 & $\begin{array}{l}\text { Level of difficulty of phrase/sentence } \\
\text { structure }\end{array}$ & 3.48 & A \\
\hline 6 & Suitability of pictures provided & 3.50 & SA \\
\hline 7 & $\begin{array}{l}\text { Appropriateness of colors (background and } \\
\text { pictures) }\end{array}$ & 3.50 & SA \\
\hline 8 & Lay-out & 3.62 & SA \\
\hline 9 & Paper size & 3.62 & SA \\
\hline 10 & Font and font size & 3.62 & SA \\
\hline 11 & $\begin{array}{l}\text { Used as material for voluntary reading } \\
\text { activities }\end{array}$ & 4.00 & SA \\
\hline 12 & Used as instructional resources/media & 4.00 & SA \\
\hline 13 & Used as inspiring materials for teachers & 4.00 & SA \\
\hline
\end{tabular}


after reading, and they will get scores and inputs of what they have done. So, follow-up activities should be available as that is how the students feel they have achieved certain 'target'. Without these activities, the students would think that they had done unimportant activities.

After evaluated by the English teachers, the ESRCs were revised based on the inputs. They agreed with the idea of giving glossary as it helps the students to understand the texts. They have proposed to give the translations of the words so the students will immediately grasp the meanings. In addition, they also agree with the EYL expert that some texts need to be shortened so as the students will not be reluctant to read. So, the revision is done accordingly to improve the quality of the ESRCs.

\section{Try-out Sessions}

In TRY-OUT 1, the students were asked to come and read when they had time and wanted to read. So, they directly showed their willingness to read. In consequently, when they read the ESRCs, they focused on what they were doing. The number of cards they read increased, and the discussions about the topics were getting intensive and critical. Although the glossary was available, the students tend to ask the researcher when they found a difficult word.

From the whole process of the TRY-OUT 1, it is found out that 1) the students are happy to choose their own preference of the reading cards; 2 ) choice allows them to select texts that they are interested in and/or find personally relevant; 3 ) the texts are basically at the students' comprehension level and linguistic competence as no student gives up reading a text in the middle of the reading process; 4) the topics are closely relevant to the students as mostly they relate the ideas from the texts with their own experience and prior knowledge; 5) expressing opinion about the texts is one reasonable way to grasp the students' understanding and ability to think critically; 6) the students have changed their perspectives about a reading activity.

TRY-OUT 2 is done classically; the ESRCs are brought into the class where the TSR can be done involving the whole group of the class. The procedure of the TSR is explained before the students start to take any cards. The results of the TRY-OUT 2 show that the product (1) provides different types of text for young learners; (2) shares various experiences dealing with different topics; (3) gives chance to deal with different kinds of tasks; (4) lets young learners express their feelings and opinions through the tasks and discussions with the researcher and their peers.

It has been agreed by reading experts that reading skill is very important. It is crucial to sharpen this skill as it is the key to young learners' success in their language competence as well as their general knowledge (Krashen, 2004; Richard-Amato, 2003; Winch et.al, 2002). Through reading for pleasure, young learners are supposed to get more varied exposure of topics and text types so motivated to explore their skill by continuing reading as they can enjoy the activity. According to Krashen (2004) and Day and Bamford (2000) the power of reading for pleasure inevitably underpins the development of reading skill and other language skills, too.

Exposed to various types of text, different topics, and relevant contents in the voluntary reading activity such as the TSR, the students are given a chance to acquire new ideas, enrich and cultivate prior knowledge, as well as reshape and reassure values and understanding. The ESRCs are available to provide those benefits which give influential experience to show the value of reading to the students as a major step in the process of becoming independent readers.

\section{CONCLUSIONS}

This study shows the use of the ESRCs for young learners as an alternative material functioning as an influential trigger of reading interest (situational interest). The material is proved to be acceptable, practical, flexible, relevant, and meaningful, which according to some reading experts (Tomlinson, 2011; Crawford, 2002) are the basic characteristics of a good acceptable reading material. If the acceptable reading material, the ESRCs, provided around young learners, some positive impacts on young learners' motivation and perception about English language as well as better insights of the importance of reading habits incidentally will start to form (individual interest).

Besides, this study contributes to an understanding of what motivates young learners to engage in English free voluntary reading program; it is an instructional strategy which is not yet recognized by most Indonesian elementary teachers and/or English teachers in elementary schools. The researcher believes that this strategy enrich the teaching of English especially the teaching of reading which may help 
many young learners acquire self-confidence and interest in learning English. So, if a free voluntary reading program is implemented in elementary schools, young learners can feel a greater sense of joy and accomplishment in reading English, and acquire English more naturally. This accomplishment and the above positive mind-set in learning English especially in reading English texts may influence other successes in learning other subjects. If the positive mind-set in learning English stays longer, it will promote young learners to find more successes as mastering English competence is undoubtedly admitted as an important and relevant competence in this global era.

\section{REFERENCES}

Andreani, S and Astuti, P.U. 2008. Pengembangan 'Reading Box' Matakuliah Reading II untuk Meningkatkan Minat Baca Mahasiswa Pendidikan Bahasa Inggris, FS-UM. Bahasa dan Seni. Tahun 39, Nomor 2, Agustus 2011.

Beare, K. 2011. Improving Reading Skills: Four Reading Skills for ESL Learners. http://esl.about.com/od/ Englishreadingskills/a/readingskill.html.

Brown, D. 2008. Why and How Textbooks Should Encourage Extensive Reading. dbrown @ nanzan-u.ac.jp

Crawford, J. 2002. Methodologyin Language Teaching: An Anthology of Current Practice. UK: Cambridge University Press.

Day, R.R. and Bamford, J. 2000. Extensive Reading in the Second Language Class. Cambridge: Cambridge University Press.

Dick, W, Carey, L and Carey, J.O. 2001. The Systematic Design of Instruction. $\left(5^{\text {th }} \mathrm{Ed}\right)$. Toronto: AddisonWesley Educational Publishers, Inc.

Dick, W and Carey, L. (1990) The Systematic Design of Instruction. New York: Harper Collin Publisher.

Doiron, R. 2003. Motivating the Lifelong Reading Habit through a Balanced Use of Children's Information Books. School Libraries Worldwide, (9)1, 39-49.

Ebbers, M. S. 2011. How to Generate Interest so Reading Comprehension Improves. sebbers@berkeley.edu

Hidi, S. 2001. Interest, Reading, and Learning: Theoretical and Practical Considerations. Educational Psychology Review, 13(3), 2001.

Hidi, S and Renninger, A. K. 2006. The Four-Phase Model of Interest Development. Educational Psychologist, 41(2), 111-127.
Hill, D. J and Flynn, M. K. 2006. Classroom Instruction that Works with English Language Learners. Virginia: Association for Supervision and Curriculum Development (ASCD)

Johnson, D. 2009. The Joy of Children's Literature. USA: Houghton Mifflin Harcourt Publishing Company

Krashen, S. 2009. 81 Generalizations about Free Voluntary Reading. IATEFL Young Learners and Teenager Special Interest Group Publication 2009-1.

Krashen, S. 2004. The Power of Reading. ( $2^{\text {nd }}$ ed.) Portmouth, NH: Heinemann.

Krashen, S. 1993. The Power of Reading. Englewood, C.O: Libraries Unlimited.

Li, Chen-Ying and Seedhouse, P. 2010. Classroom Interaction in Story-based Lessons with Young Learners. Asian EFL Journal, 12( 2), Article 13.

Listia, R and Kamal, S.2009. Kendala Pengajaran Bahasa Inggris di Sekolah Dasar. Pgingfkipunlam.

Loh, K.K.J. 2009. Teacher modeling: Its impact on an extensive reading program. Reading in a Foreign Language. October 2009, 21(2).

McClure, T.C. 2008. Creating early, engaged learners. www.edvantia.org.

Mesmer, H.A.E. 2008. Tools for Matching Readers to Texts. New York: The Guilford.

Nation, I.S.P. 1997. The language Benefits of Extensive Reading. The Language Teacher, 21(5). Retrieved from http://www.jalt.publication.org/tlt/files/97/ may/benefits.html.

Nishino, T. 2007. Beginning to Read Extensively: a Case Study with Mako and Fumi. Reading in Foreign Language. 19(2), pp. 76-105.

Rachmajanti, S. 2005. The Impact of the Teaching of English at the Elementary Schools on the Students' Achievement of English at the First year of Lower Secondary School. Dissertation: Unpublished.

Richard-Amanto, P.A. 2003. Making It Happen: from Interactive to Participatory Language Teaching. NY: Pearson Education, Inc.

Scott, J.A and Nagy, W.E. 2004. Developing Word Consciousness. In F.J. Baumann and J.E. Kame'enul (Eds). Vocabulary Instructions: Research to Practice. NY: Guilford Press.

Tomlinson, B. 2011. Materials Development in Language Teaching. Second Edition. Cambridge: Cambridge University Press.

Winch, G et al. 2002. Literacy: Reading, Writing, and Children's Literature. Oxford: Oxford University Press. 